\title{
The Use of Guided Discovery Learning Model In Mathematics Subject
}

\author{
Rafika Said $^{1}$, Sudiyanto ${ }^{2}$, and Budi Usodo ${ }^{3}$ \\ \{rafikasaid85@gmail.com ${ }^{1}$, sudiyanto@staff.uns.ac.id ${ }^{2}$,budi_usodo@staff.uns.ac.id ${ }^{3}$ \} \\ ${ }^{1,2,3}$ Sebelas Maret University, Surakarta, Indonesia
}

\begin{abstract}
One of the mathematics purposes in education is the ability to solve problems of mathematics, another subject or problems in connection with everyday life. Guided discovery learning model is one of the learning models in which a teacher can choose to help students solve the difficulties in learning mathematics. According to Bruner, discovery learning is a learning process in which a student encounters a problem, then he or she is able to discover the solution to his or her own problems. During the learning activities, students are expected to be able to find something, formulate hypotheses, or draw a conclusion themselves while the teacher acts as a facilitator who guides the students when the teacher is needed. This research aims to explain the use of Guided Discovery learning model in mathematics subject. The research uses descriptive qualitative method, which is to collect data from various sources, to read the data repeatedly and then to write down the data in line with the research objectives. The results show that guided discovery can increase students' motivation and learning achievement in mathematics.
\end{abstract}

Keywords: guided discovery, mathematics, learning achievement

\section{INTRODUCTION}

Mathematics education is one of disciplines in education that is needed by humans. According to Mahanta [1], he argues that learning mathematics is essential for students even for countries throughout the world because the calculation skills in mathematics are very important and useful in every step of life. Mathematics education in Indonesia is still relatively low compared to other countries. This is based on data from a study conducted by Trends in the International Mathematics and Science Study (TIMSS) in 2015 Indonesia that ranked 45th out of 50 countries. From the data of Trends in International Mathematics and Science Study (TIMSS), it was found that in the domain of knowing or working routine computational questions, $57 \%$ of students could answer correctly, while in the domain of applying those questions, only $4 \%$ of students gave 
answers correctly. Subsequently in the domain of reasoning, the average of correct students' answers is 20 , while the International average of them is 44 .

The low level of education in Indonesia, especially mathematics, is as a result of many factors. Slameto [2] argues that the low student achievement can emanate from several factors including students themselves, instruments, and environment. Factors originating from students themselves include physiological aspects such as health and disability factors, and psychological aspects such as intelligence, attention, interest, talent, motives, maturity and fatigue. Factors originating from the instruments are curriculum, teachers, tools, facilities, and administration/programs. Meanwhile, the factors originating from the environment are parents' socio-economic issue, home environment, house geographical location, playmates, climate, and cultural background.

The practice of learning mathematics in Indonesia has always been teacher-centered. The teacher is still dominating in the learning process, especially on mathematics subject. The teacher delivers the lesson using the lecture method and students write down the lesson in their notebook, and then they work on the exercise questions. This makes students in schools think that learning mathematics is not fun and it only becomes a routine without any awareness to add insight. In fact, mathematics itself is very useful in everyday life. So far, students only took for granted mathematics learning in schools, without questioning why or for what mathematics was taught. The use of teacher learning model is not appropriate, which makes mathematics learning become boring so that students are less interested in mathematics subject and this impacts on low mathematics learning achievement.

Therefore, learning model that makes students active in learning is needed in which the model makes students not only listen, take notes, and do exercises, but also experience the learning process so that they feel interested and joyous in learning mathematics. One of the alternatives to change this learning is learning by means of Guided Discovery depending on the characteristics of the students. In the Guided Discovery (GD) learning model, learning activities are not dominated by teachers, but students are asked to play an active role in learning because the Guided Discovery (GD) learning model makes students find their own results with the guidance of their teacher. This is in line with the opinion of Sri Lestari [3] in her research in 2011 stating that the Guided Discovery learning model is a useful teaching method for mathematics learning. In this model, students are encouraged to think for themselves so that they can find general principles based on materials facilitated by the teacher. In this learning model, students are more dominant in learning activities and the role of the teacher turns into a facilitator in learning and thus, students are active in learning, discover the concepts of subject matter themselves, and make learning more enjoyable.

\section{METHOD}

This study uses a qualitative descriptive design. It means that the results of the study are presented to describe the quality. According to Hidayat Syah [4], descriptive research is a research method used to find knowledge that is as extensive as possible for the object of research at a point of time. Whereas according to Punaji Setyosari [5], descriptive research is a research aiming to explain or describe a situation, event, object, person, or everything related to variables that can be explained either by figures or words. The source of the data in this research is guided discovery learning model to improve the achievement in matematics learning. To get the data needed, the 
researchers use reading and note-taking for data collection technique. The source of the data is read repeatedly, intensely and carefully to get data that suits the research objectives. Then, the data that has been found is written down in the form of notes. In searching for data, the researchers set the instrument, which is the researchers themselves. Meanwhile, the data analysis technique used in this research is the content analysis technique. It means that researchers analyze the data that has been collected to find the meaning contained in it in line with the purpose of the research.

\section{RESULTS AND DISCUSSION}

Several definitions with regard to "model" exist, among others in the Indonesian Dictionary [6], model has examples of meaning; pattern; reference; variety. While according to Dakir [7], model is a theoretical construction of concepts.

The concept of learning according to Corey [8] is "a process in which a person's environment is intentionally managed to allow him or her to participate in certain behaviors under special conditions or produce responses to certain circumstances. Learning is a special subset of education." In the Minister of National Education Regulation Number 41 of 2007 concerning Standard Processes for Primary and Secondary Education Units, it is described that:

"Learning is the process of interaction between students, teachers, and learning resources in a learning environment. The learning process needs planning, implementing, assessing, and monitoring. The implementation of learning is an application of RPP/lesson plan. The implementation of learning includes preliminary activities, core activities and closing activities."

According to Rusman [9], learning model is a plan or pattern that can be used to form a curriculum (long-term learning plan), design learning materials, and guide learning in the classroom and so forth. Soekamto, et al. [10] suggested the purpose of the learning model is:

"A conceptual framework that describes systematic procedures in organizing learning experiences to achieve specific learning goals, and serves as a guide for learning designers and instructors in planning teaching and learning activities."

Jerome Bruner's learning theory is well-known for discovery learning theory. Discovery learning from Jerome Bruner is a model of teaching that is developed and based on constructivist principles. In discovery learning, students are encouraged to learn on their own independently. Students are actively involved in the discovery of concepts and principles through problem solving or the results of abstraction as cultural objects. The teacher encourages and motivates students to gain experiences by carrying out activities that enable them to discover mathematical concepts and principles for themselves. This learning can inspire students to become more curious. Jerome Bruner in Trianto [11] states that discovery learning is in line with the active search for knowledge by humans and hence giving good results. Making efforts on our own to find solutions to problems and their accompanying knowledge will produce meaningful knowledge. Whereas according to Slameto [12] that in the learning process, Jerome Bruner emphasizes the active participation of each student and knows well that there are differences in their ability. To improve the learning process needs an environment called exploration, unknown new discoveries or understandings that are similar to those already known. 
Meanwhile, according to Martaida, Bukit, Ginting [13], they state that the discovery learning model is a series of learning activities emphasizing critical thinking process and analysis to achieve and find their own answers to the problems raised. The essence of discovery learning is to give students lessons to deal with problems encountered by them who face the real world.

The learning process on discovery learning can involve teacher guidance whether fully or not at all. Two kinds or types of discovery learning are pure discovery learning (free discovery) and directed discovery learning (guided discovery). Pure discovery learning (free discovery) is discovery learning without instructions or direction. Whereas directed/guided discovery is learning that requires the role of the teacher as a facilitator in the learning process.

This is in line with the opinion of Jacobsen, Eggen, Kauchak [14] in Guided Discovery in which the teacher has role as a facilitator. The teacher acts as a guide and helps students to use their ideas, concepts and skills. Students are encouraged to think and analyze themselves so that they can find general principles based on materials or data provided by the teacher. The implementation of learning with this model indeed requires a relatively long time, but if done effectively, this model tends to produce long-term memories and transfers that are better than learning with the expository model. The same thing is expressed by Abel and Smith [15] that in guided discovery learning, the teacher acts as a facilitator who guides students through questions that lead students to think for themselves and analyze themselves.

Whereas according to Hamalik [16], guided discovery learning involves students in answering teacher questions. Students carry out discovery activities, while the teacher guides them to obtain generalizations that are appropriate to the learning objectives.According to Hanafiah and Suhana [17], this implementation starts from the core question, the teacher asks various questions to track, with the aim of directing students to the expected conclusion point. Then the students conduct an experiment to prove the expressed opinions.

According to Hosnan [18], the positive role of guided discovery learning includes encouraging students to think and work on their own initiatives, encouraging students to form their own hypotheses, helping students strengthen their own concepts because they gain trust in working with others. From these definitions and roles, guided discovery is very suitable for developing students' mastery of mathematical concepts.

According to Eggen \& Kauchak, [19] the purpose of the fourth characteristic is that the learning presented by the teacher is an existing and standardized concept. However, students try to explore information and rediscover the concept based on their understanding and subject to their version so that the information and concept are not easily forgotten.

According to Bruner [20], the Guided Discovery (GD) learning steps are: Stimulus, Problem statement, Data collection, Data processing, Verification, and Generalization.

According to Muhibbin [21], the stages of implementing guided discovery learning are Stimulus (giving stimulants); learning activities begin by providing questions that stimulate students' thinking, advise and encourage them to read books and other learning activities that lead to preparation for problem solving. Problem statement: providing opportunities for students to identify as many problems as possible that are relevant to the subject matter, and then choose and formulate them in the form of a hypotheses (temporary answers to the problems). Data collection: providing opportunities for students to gather relevant information as much as possible to prove the truth of their hypotheses. Data processing: processing data that has been obtained by students through interviews, observations, and others. The data is then interpreted. Verification: holding a 
careful examination to prove the correctness of the hypotheses set with the results of data processing. Generalization: drawing conclusions to be used as general principles that apply to all the same events or problems with regard to the results of verification.

The advantages of Guided Discovery learning according to Markaban [22] are as follows: students are active in learning activities because they think and use their abilities to find the final results; a medium is provided for interaction between students as well as between students and the teacher; and the learned materials can reach a high level of ability and longer durability because students are involved directly in the process of discovery; students' problem solving abilities are supported; students understand correctly the subject matter because they experience their own process; something that is obtained in this way is longer remembered; finding on their own creates a sense of satisfaction and this inner satisfaction encourages them to make more discoveries until interest in learning increases; students who acquire knowledge with the discovery method will be better able to transfer their knowledge to various contexts. This method trains students to learn more on their own, and the learning situation becomes more exciting. Besides its advantages, the guided discovery learning also has disadvantages, which are: this method takes a lot of time and it does not guarantee that students are eager to find discoveries; not all students can take lessons in this way; not all topics are suitable to be delivered by this method; not every teacher has the tendency or ability to teach by means of discovery; and not all children are able to make discoveries. If the teacher's guidance is not in line with the intellectual readiness of students, this can damage the structure of their knowledge, and too much guidance can turn off their initiatives, as well as classes with many students will be very troublesome for the teacher to provide guidance and direction to learning with discovery. Based on this explanation, it can be concluded that the teacher needs to pay attention to the advantages that exist and try to utilize these advantages. However, the teacher also needs to be aware of the shortcomings so that the guided discovery learning can have positive impacts on the learning process [25].

Up to date, the findings or results of researches related to the guided discovery learning have been discovered through many studies, not to mention the guided discovery learning in mathematics learning. These are the results from a research by Yurniwati and Latipa Hanum [23] in 2017 entitled "Improving Mathematics Achievement of Indonesian 5th Grade Students Through Guided Discovery Learning".In their research, it is stated that the use of Guided Discovery model can improve students' learning achievement, with an average increase of students reaching the first KKM (minimum completeness criteria) cycle of $64.2 \%$, in the second cycle of $71.4 \%$, and the third cycle of $85.7 \%$.

Kiki Yuliani, Sahat Saragih [22] in 2015 with their research title "The Development of Learning Devices Based Guided Discovery Model to Improve Understanding Concept and Critical Thinking Mathematically Ability of Students at Islamic Junior High School of Medan" in the Journal of Education and Practice.The results of the research state that the use of Guided Discovery model can improve the concept understanding with the average achievement of concept understanding of 77.92 in the first trial, increasing to 81.81 in second trial, and critical thinking of mathematical abilities in the first trial amounts to 73.88 , increased to 77.58 in the second trial. 


\section{CONCLUSION}

Mathematics learning requires high cognitive abilities, and students also have to do mental processes in their mind by linking one mathematical concept with other concepts. As a result, this will make it difficult for students to understand mathematics correctly and quickly. To overcome these problems, the guided discovery learning model is one of the learning models that teachers can choose to help students solve difficulties in learning. Guided discovery learning is a discovery learning model carried out by students based on the teacher's instructions. Instructions are given generally in the form of a guiding statement in which as a facilitator, the teacher guides the students whenever the teacher is needed. In this learning model, students are encouraged to think for themselves so that they can find general principles based on the material or data provided by the teacher. The extent of students being guided in learning depends on their abilities and what material is under studying. The use of Guided Discovery makes it easy for students to understand mathematics. The reason is that in the Guided discovery learning model, students find their own learning outcome with guidance from the teacher.

\section{REFERENCES}

[1] Mahanta, Dibyajyoti. Achievement in Mathematics: Effect of Gender and Positive/Negative Attitude of Students. International Journal of Theoretical \& Applied Sciences, 4(2): 157163. 2012.

[2] Slameto, Belajar Dan Faktor-Faktor Yang Mempengaruhinya, Jakarta.: Binaaksara. 2003.

[3] Sri Lestari. Eksperimentasi Model Pembelajaran Penemuan Terbimbing (Guided Discovery) dan Model Pembelajaran Missouri Matematics Project (MMP) terhadap Prestasi Belajar Matematika Ditinjau dari Kemampuan Awal Siswa di SMK Kabupaten Klaten. Surakarta: UNS. 2011.

[4] Hidayat Syah.Pengantar Umum Metodologi Penelitian Pendidikan Pendekatan Verivikatif. Pekanbaru : Suska Pres. 2010.

[5]Punaji Setyosari. Metode Penelitian Pendidikan dan Pengembangan. Jakarta: Kencana. 2010.

[6]Depdikbud. Kamus Besar Bahasa Indonesia. Jakarta: PN. BalaiPustaka. 2005.

[7] Dakir. Perencanaan dan Pengembangan Kurikulum. Jakarta:RenikaCipta. 2004.

[8] Sagala, S. Konsep dan Makna Pembelajaran. Bandung: Alfabeta. 2010.

[9] Rusman. Model-Model Pembelajaran: Mengembangkan Profesionalisme Guru, Jakarta: Rajawali Pers. 2011.

[10] Trianto. Desain Pengembangan Pembelajaran Tematik Bagi Anak Usia Dini TK/RA dan Anak Usia Kelas Awal SD/MI, Jakarta: Kencana. 2011.

[11] Trianto. Model-model Pembelajaran Inovatif Berorientasi Konstruktifistik, Surabaya: Prestasi Pustaka Publisher. 2007.

[12] Slameto.Belajar Dan Faktor-Faktor Yang Mempengaruhinya, Jakarta.:Binaaksara. 2003.

[13] Martaida, T, Bukit, N, Ginting.E.M. The Effect of Discovery Learning Model on Student's Critical Thinking and Cognitive Ability in Junior High School. IOSR Journal of Research \& Method in Education (IOSR-JRME)Volume 7, Issue 6 Ver. I (Nov. - Dec. 2017), PP 01-08. 2017.

[14] Jacobsen, David A, dkk, .Method for Teaching, Yogyakarta: PustakaPelajar. 2009. 
[15] Abel, S. \& Smith, D. What Is Science? Preservice Elementary Teachers' Conceptions of The Nature of Science. International Journal of Science Education (IJSE). 1994.

[16] Hamalik, Oemar. Perencanaan Pengajaran Matematika Berdasarkan Pendekatan Sistem. Jakarta: Bumi Aksara. 2005.

[17] Hanafiah, N danSuhana, C. Konsep Strategi Pembelajaran. Bandung: Aditama. 2009.

[18] Hosnan. PendekatanSaintifik dan Kontekstual Dalam Pembelajaran Abad 21. Bogor: Ghalia Indonesia. (2014)

[19] Eggen, P., Kauchak, D. Strategidan model pembelajaran: mengajarkan konten dan keterampilan berfikir. Terj Satrio Wahono. Boston: Perason Education Inc.(2012)

[20] Norsanty, U. O., dan Zahra Chairani. Pengembangan Lembar Kerja Siswa (LKS) Materi Lingkaran Berbasis Pembelajaran Guided Discovery untuk Siswa SMP Kelas VIII. Jurnal Pendidikan Matematika. Volume 2. (2016)

[21] Qorri'ah. Penggunaan Metode Guided Discovery Learning Untuk Meningkatkan Pemahaman Konsep Pada Pokok Bahasan Bangun Ruang Sisi Lengkung, Jakarta: UIN Syarif Hidayatullah, pp. 19-21.(2011)

[22] Markaban, ModelPenemuanTerbimbingPadaPembelajaranMatematika. Yogyakarta: DEPDIKNAS, PPTKM. (2008)

[23] Yurniwati, Hanum.L."Improving Mathematics Achievement of Indonesian $5^{\text {th }}$ Grade Students Through Guided Discovery Learning". Journal on Mathematics Education Volume 8, No. 1, January 2017, pp. 77-84.(2017)

[24] Yuliani K, Saragih S. The Development of Learning Devices Based Guided Discovery Model to Improve Understanding Concept and Critical Thinking Mathematically Ability of Students at Islamic Junior High School of Medan. Journal of Education and PracticeVol.6, No.24, (2015)

[25] K. Saddhono and M. Rohmadi, "A Sociolinguistics Study on the Use of the Javanese Language in the Learning Process in Primary Schools in Surakarta, Central Java, Indonesia." Int. Edu. Stu., vol. 7 no.6 pp 25-30, 2014 